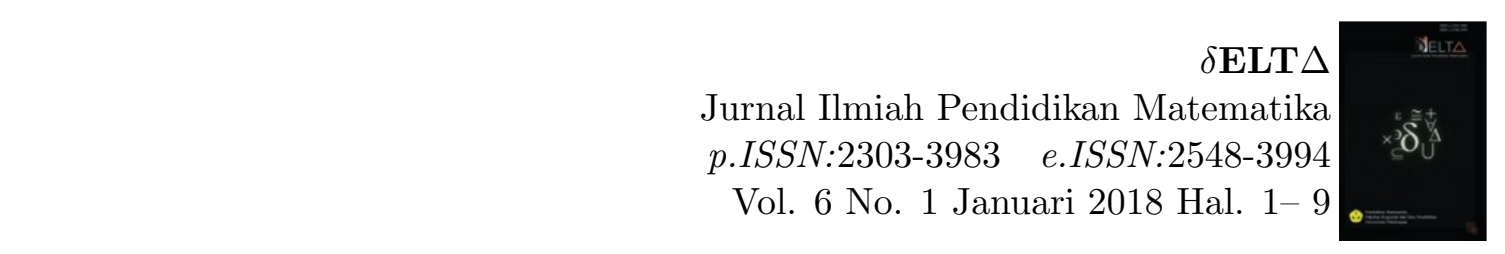

\title{
EFEKTIVITAS PPL UNTUK MENINGKATKAN EFIKASI DIRI MENGAJAR PADA MAHASISWA PENDIDIKAN MATEMATIKA
}

\author{
Aji Cokro Dewanto \\ UNIVERSiTAS PEKALONGAN \\ cokrodewanto@yahoo.com
}

\begin{abstract}
Abstrak
Mata pelajaran matematika masih dianggap sukar oleh sebagian besar siswa, hal ini menjadi tantangan bagi guru matematika untuk dapat mengajarkan matematika secara baik. Oleh karena itu, calon guru matematika perlu memiliki efikasi diri terhadap kemampuannya dalam mengajarkan materi matematika. Penelitian ini bertujuan untuk mengetahui seberapa besar efektivitas praktik pengalaman lapangan untuk meningkatkan efikasi diri mengajar pada 15 mahasiswa program studi Pendidikan Matematika, Fakultas Keguruan dan Ilmu Pendidikan Universitas Pekalongan, Semester VII Tahun Pelajaran 2017/2018. Penelitian ini menggunakan metode eksperimen dengan desain one group pretest - posttest. Variabel efikasi diri mengajar diukur menggunakan Skala Efikasi Diri Mengajar yang telah diujikan kepada 105 mahasiswa Fakultas Keguruan dan Ilmu Pendidikan Universitas Pekalongan semester VII, dengan hasil koefisien reliabilitas alpha cronbach sebesar 0,966. Hasil penelitian ini menunjukkan adanya peningkatan signifikan rata-rata skor efikasi diri mengajar sebesar 23,76\%, dengan nilai signifikansi sebesar $0,001(p<0,05)$. Analisis lnjutan terhadap aspek-aspek efikasi diri mengajar menunjukkan bahwa aspek magnitude meningkat sebesar 26,73\% $(p<0,05)$, aspek generality meniningkat sebesar $22,60 \%(p<0,05)$, dan aspek strength meningkat sebesar $28,48 \%(p<0,05)$. Dengan demikian, dapat disimpulkan bahwa praktik pengalaman lapangan dapat meningkatkan efikasi diri mengajar pada mahasiswa pendidikan matematika secara signifikan.
\end{abstract}

Kata kunci: praktik pengalaman lapangan, efikasi diri mengajar, pendidikan matematika

\begin{abstract}
Most students consider mathematics is a difficult subject, and it becomes a challenge for the teachers to teach the subject in a good way. Therefore, future mathematics teachers need self-efficacy in teaching the subject. This research aims to find out the effectivity of field experience practice to increase teaching self-efficacy in 15 students of Mathematics Education Program, Teaching and Education Departement of Universitas Pekalongan, Semester VII 2017/2018 period. This research implemented experiment method with the one group pretest-posttest design. Teaching self-efficacy variable was measured by Teaching Self-Efficacy Scale which was tested to 105 students of Teaching and Education Departement Universitas Pekalongan semester VII, the result of aplha croncbach reliability coefficient was 0,966 . This research showed a significant increase in teaching self-efficacy mean for $23,76 \%$, with the significance of $0,001(p<0,05)$. Further analysis for the aspects of teaching self-efficacy showed that magnitude aspect was increase for $26,73 \%(p<0,05)$ generality aspect was increase for 26,73\% $(p<0,05)$, and strength aspect was increase for $26,73 \%(p<0,05)$. In conclusion, field experience practice could significantly increase teaching self-efficacy of mathematics education students.
\end{abstract}

Keywords: field experience practice, teaching self-efficacy, mathematics education

\section{Pendahuluan}

Pembukaan Undang-Undang Dasar 1945 alinea ke-4 menyebutkan bahwa salah satu tujuan bangsa Indonesia adalah mencerdaskan kehidupan bangsa. Tujuan ini senantiasa diupayakan melalui proses pendidikan. UU No. 20 Tahun 2003 Pasal 1 Ayat 1 menyebutkan bahwa "pendidikan adalah usaha sadar dan terencana untuk mewujudkan suasana belajar dan proses pembelajaran agar peserta didik secara aktif mengembangkan potensi 
dirinya untuk memiliki kekuatan spiritual keagamaan, pengendalian diri, kepribadian, kecerdasan, akhlak mulia, serta ketrampilan yag diperlukan dirinya, masyarakat, bangsa, dan negara."

Pengemban tugas untuk mendidik tidak lain disematkan kepada profesi guru. Hal tersebut tercantum dalam Peraturan Pemerintah Republik Indonesia No. 74 Tahun 2008 Pasal 1 Ayat 1 yang menyebutkan bahwa "guru adalah pendidik profesional dengan tugas utama mendidik, mengajar, membimbing, mengarahkan, melatih, menilai, dan mengevaluasi peserta didik pada pendidikan anak usia dini jalur pendidikan formal, pendidikan dasar, dan pendidikan menengah." Dengan tugas yang sedemikian penting, tentu dibutuhkan sumber daya guru yang bermutu dan memenuhi standar kualitas sebagaimana diatur dalam UU No. 14 Tahun 2005 Bab IV Pasal 8, yaitu "guru wajib memiliki kualifikasi akademik, kompetensi, sertifikat pendidik, sehat jasmani dan rohani, serta memiliki kemampuan untuk mewujudkan tujuan pendidikan nasional."

Kualifikasi akademik tersebut dapat dicapai dengan menempuh proses pendidikan di Fakultas Keguruan dan Ilmu Pendidikan. Mahasiswa keguruan diharapkan mampu memenuhi standar kompetensi sebagai calon guru, termasuk mahasiswa di program studi Pendidikan Matematika. Hal tersebut menjadi penting mengingat matematika merupakan salah satu mata pelajaran yang dijadikan standar umum dalam Ujian Nasional. Namun, matematika ternyata masih dianggap sulit oleh siswa di kawasan Asia Pasifik sebagaimana menjadi pembasan utama dalam The 4 th Consortium of Asia-Pasific Education Universities di Universitas Negeri Surabaya pada 22-23 Mei 2017.

Sulitnya materi pelajaran matematika juga masih dirasakan oleh mahasiswa pendidikan matematika. Berdasarkan wawancara peneliti yang dilakukan terhadap dosen pendidikan matematika di Universitas Pekalongan, diperoleh informasi bahwa sebagian mahasiswa pendidikan matematika yang masih kurang percaya diri dan memiliki perasaan takut salah dalam menyampaikan materi matematika.

Kondisi tersebut menunjukkan bahwa terdapat mahasiswa pendidikan matematika yang memiliki efikasi diri mengajar rendah. Efikasi diri merupakan konsep yang dikembangkan oleh Albert Bandura, dengan pengertian berupa keyakinan seseorang bahwa ia memiliki kemampuan untuk mengelola dan melakukan suatu tindakan tertentu. Efikasi diri dapat ditinjau dari situasi tertentu, yang dalam hal ini adalah situasi mengajar. Pajares dan Kranzler menyatakan bahwa efikasi diri mengajar merupakan keyakinan individu tentang kemampuannya untuk berhasil melakukan atau menyelesaikan tugas mengajar Ghufron, 2017. Hal itu sejalan dengan definisi yang dicetuskan oleh Gavora mengenai efikasi diri guru, yaitu keyakinan diri personal pada guru terkait kemampuannya untuk merencanakan dan menyelesaikan tugas mengajar Gavora, 2010. Dengan demikian, efikasi diri dalam mengajar pada penelitian ini dapat didefinisikan sebagai keyakinan seseorang terkait kemampuannya dalam mempersiapkan dan melaksanakan pengajaran.

Efikasi diri merupakan hal penting karena menjadi variabel kunci yang mempengaruhi penggunaan strategi belajar dan evaluasi diri Mukhid, 2009. Dalam hal ini, mahasiswa pendidikan matematika yang memiliki efikasi diri rendah dapat semakin mengalami kesulitan untuk memahami materi pelajaran, yang berimplikasi pada kompetensi profesionalitasnya ketika menjadi guru kelak. Penelitian Safaria menunjukkan bahwa efikasi diri memiliki sumbangan terhadap kematangan karir mahasiswa. Tingkat efikasi diri yang rendah membuat mahasiswa semakin ragu dan bimbang untuk menekuni karir maupun profesi tertentu Safaria, 2016. Seorang mahasiswa keguruan bisa menjadi tidak yakin untuk dapat menjadi guru, dan justru beralih ke profesi lain ketika ia merasa tidak memiliki kemampuan dalam melaksanakan tugas-tugas profesi guru kelak. Hal itu disebakan oleh meningkatnya kecemasan dan perilaku menghindar akibat efikasi diri yang rendah Rustika, 2012.

Bandura menyatakan bahwa terdapat tiga aspek yang mendasari keyakinan seseorang untuk mampu melakukan sesuatu tindakan tertentu ([Putri and Priambodo, 2015]). 
Ketiga aspek tersebut diperoleh dengan pengembangan indikator mengadaptasi Ardiyanti Ardiyanti, 2016 yang disesuaikan untuk konteks mengajar, yaitu:

1. Magnitude (tingkat kesulitan) terkait dengan perasaan mampu menyelesaikan tugas mengajar dengan beragam tingkat kesulitan. Semakin seseorang merasa mampu menyelsaikan tugas yang sulit, maka semakin tinggi efikasi dirinya. Terdapat dua indikator, yaitu a) keyakinan dalam menghadapi tugas mengajar yang sulit, dan b) keyakinan dalam merencanakan tugas mengajar.

2. Generality (rentang keluasan bidang) terkait dengan keyakinan untuk mampu menyelesaikan tugas mengajar dalam rentang kondisi yang beragam. Semakin seseorang merasa mampu mengatasi aneka macam tugas, maka semakin tinggi efikasi dirinya. Terdapat dua indikator, yaitu a) keyakinan dalam menghadapi berbagai situasi ketika mengajar, dan b) keyakinan untuk mengantisipasi situasi mengajar yang belum pernah dialami.

3. Strength (tingkat kekuatan) terait dengan kemampuan seseorang untuk bertahan dalam mengatasi keadaan ketika mengajar. Semakin ia mampu bertahan dalam situasi tertentu, semakin tinggi efikasi dirinya. Terdapat dua indikator, yaitu a) bertahan lebih lama saat mengalami kesulitan dalam mengajar, dan b) keuletan dalam berusaha mengatasi tantangan ketika mengajar.

Efikasi diri bukan sesuatu yang paten atau menetap, sehingga dapat dilakukan upaya peningkatan. Bandura ([Bandura, 1994 dan Bandura, 1997]) menyebutkan empat sumber yang dapat meningkatkan efikasi diri, sebagaimana dijelaskan lebih lanjut oleh Muretta.

1. Mastery experience (pengalaman keberhasilan) merupakan sumber paling kuat dalam menumbuhkan efikasi diri. Hal ini disebabkan oleh dua hal. Pertama, pengalaman berhasil bersifat personal dan langsung. Kedua, biasanya disebabkan oleh usaha dan kemampuan diri sendiri.

2. Vicarious experience (keberhasilan orang lain yang setara) merupakan sumber terkuat kedua dalam menumbuhkan efikasi diri. Dalam hal ini, seseorang akan mengalami peningkatan efikasi diri terkait suatu tugas apabila ia mengetahui orang lain dengan kondisi yang setara dengannya telah berhasil melakukan tugas tersebut. Keberhasilan orang lain seolah-olah ia rasakan sendiri. Sumber ini terkait dengan proses belajar observasional.

3. Verbal persuation (persuasi verbal) bisa berupa ucapan penyemangat, dorongan, nasehat, dan perbincangan positif lainnya. Adanya persuasi verbal akan membuat seseorang memberikan upaya yang lebih gigih untuk mencapai keberhasilan dalam tugas.

4. Physiological arousal (kondisi fisiologis dan suasana hati) di mana kondisi letih, sakit, atau sedih akan dikaitkan dengan efikasi diri yang rendah. Hal itu disebabkan seseorang cenderung memberikan penilaian negatif kepada diri sendiri saat tidak dalam kondisi fisik maupun suasana hati yang bagus.

(Muretta, 2005)

Berdasarkan uraian tersebut dapat disimpulkan bahwa efikasi diri dapat ditingkatkan salah satunya melalui pengalaman akan keberhasilan, baik yang dialami oleh diri sendiri maupun orang lain. Kolb, Boyatzis, dan Mainemelis (Kolb et al., 2001]) mendefinisikan belajar berdasarkan pengalaman (experiential learning) sebagai proses di mana pengetahuan diperoleh melalui pembentukan pengalaman. Belajar berdasar pengalaman merupakan konsep yang dicetuskan oleh David Kolb pada tahun 1984, dan terdapat empat aspek yang saling berkelanjutan selama proses belajar berdasarkan pengalaman, yaitu 


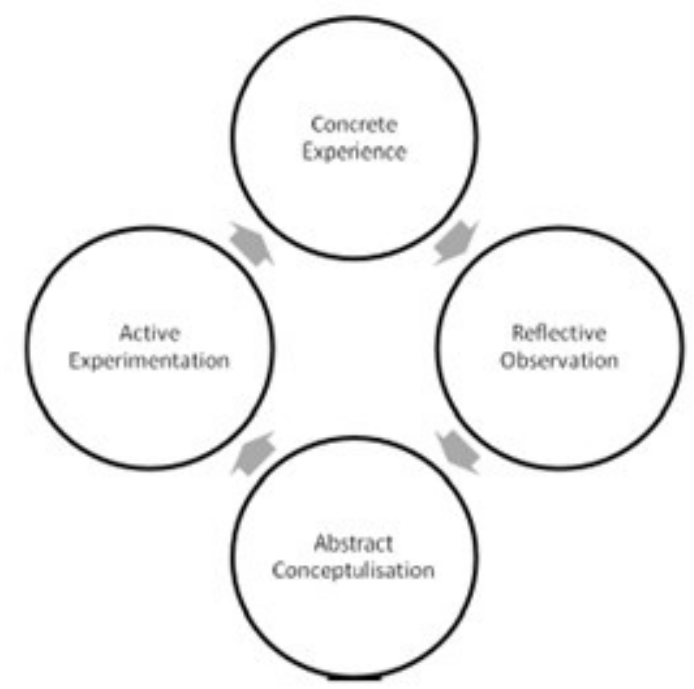

Gambar 1: Alur belajar berdasarkan pengalaman

1. Concrete experience yaitu mengalami secara nyata tugas yang ingin dipelajari.

2. Abstract conceptualization yaitu melakukan analisis dan perencanaan terhadap tugas yang dipelajari.

3. Reflective observation yaitu melakukan pengamatan kepada orang lain terkait tugas yang dipelajari.

4. Active experimentation yaitu mencoba cara-cara baru untuk dapat menyelesaikan tugas yang dipeajari secara lebih baik.

(Mughal and Zafar, 2011)

Keempat hal tersebut juga dikembangkan oleh Kolb sebagai karakteristik gaya belajar. Model ini memiliki enam asumsi dalam pembelajaran, yaitu: a) belajar adalah proses dan bukan hasil, b) belajar ditentukan oleh pengalman, c) belajar menuntut pembelajar untuk memecahkan persoalan, d) belajar harus dipandang secara lebih menyeluruh, e) belajar menuntut pembelajar untuk berinteraksi dengan lingkungan, f) belajar menghasilkan ilmu pengetahuan. Gambar 1 merupakan gambar alur belajar berdasarkan pengalaman.

Kolb menyatakan bahwa cukup banyak institusi pendidikan yang menerapkan model belajar berdasarkan pengalaman (Kolb, 2014). Program pembelajarannya bisanya berupa magang, proyek lapangan, dan simulasi. Terkait dengan upaya pengembangan keterampilan, dikenal istilah on the job training, yang menempatkan pembelajar untuk menerapkan perilaku/keterampilan yang telah dipelajari pada situasi nyata. Hal ini merupakan cara terbaik untuk mengembangkan keterampilan dan sikap, serta memiliki pengaruh kuat terhadap peningkatan kreativitas, dan kualitas kerja (Alipour et al., 2009). Tujuan dari on the job training adalah membekali pembelajar dengan pengetahuan spesifik terkait tugas dan keterampilan di wilayah kerja. Dengan demikian, magang termasuk dalam on the job training.

Magang bagi mahasiswa Fakultas Keguruan dan Ilmu Pendidikan dilakukan melalui Praktik Pengalaman Lapangan (PPL). Mahasiswa praktikan belajar banyak mengenai kurikulum, praktik pembelajaran, manajemen sekolah, administrasi pendidikan, dan kegiatan kesiswaan. Selain itu, mahasiswa praktikan juga dibimbing oleh guru pamong dan dosen pembimbing lapangan. Tujuan utama dari PPL FKIP Universitas Pekalongan 
adalah menghasilkan calon lulusan yang terlatih dalam melakukan proses belajar mengajar di kelas. Dalam penelitian ini, dikhususkan pada mahasiswa pendidikan matematika sebagaimana telah dipaparkan sebelumnya. Dengan demikian, tujuan penelitian ini adalah mengetahui efektivitas PPL untuk meningkatkan efikasi diri mengajar pada mahasiswa pendidikan matematika.

\section{Metode Penelitian}

\subsection{Jenis Penelitian}

Penelitian ini menggunakan metode eksperimen dengan desain one group pretest - posttest, yaitu pengukuran dilakukan kepada subjek penelitian, kemudian perlakuan diberikan, diikuti pengukuran kepada subjek penelitian yang sama Cook et al., 2002. Penelitian ini menggunakan pendekatan kuantitatif.

\subsection{Waktu dan Tempat Penelitian}

Penelitian ini dilaksanakan pada bulan Agustus hingga Oktober 2017 pada semester gasal tahun pelajaran 2017/2018 selama Praktik Pengalaman Lapangan (PPL) Fakultas Keguruan dan Ilmu Pendidikan Universitas Pekalongan. Penelitian dilaksanakan di Universitas Pekalongan dan beberapa sekolah di Kabupaten Pekalongan tempat pelaksanaan PPL.

\subsection{Target/Subjek Penelitian}

Subjek penelitian adalah mahasiswa Program Studi Pendidikan Matematika, Fakultas Keguruan dan Ilmu Pendidikan Universitas Pekalongan semester VII, yang mengikuti Praktik Pengalaman Lapangan. Subjek penelitian berjumlah 15 orang yang terdiri dari 13 perempuan dan 2 laki-laki. Teknik purposive sampling digunakan untuk menyeleksi subjek penelitian yang memiliki skor efikasi diri mengajar pada kategori rendah dan sedang.

\subsection{Prosedur Penelitian}

Penelitian diawali dengan pengembangan skala pengukuran Efikasi Diri Mengajar. Setelah itu dilakukan proses sampling subjek penelitian sekaligus sebagai pre-test. Intervensi yang diberikan berupa Praktik Pengalaman Lapangan, dilanjutkan dengan pelaksanaan post-test kepada subjek penelitian.

\subsection{Data, Instrument, dan Teknik Pengumpulan Data}

Data yang digunakan dalam penelitian ini adalah skor pre-test dan post-test yang diperoleh subjek penelitian. Alat ukur yang digunakan adalah Skala Efikasi Diri Mengajar yang dikembangkan dari teori Bandura Bandura, 1997 mengenai efikasi diri, dengan format likert yang terdiri atas 24 butir pernyataan. Pengembangan indikator dalam skala ini mengacu pada penelitian Ardiyanti Ardiyanti, 2016. Skala tersebut telah divalidasi secara kualitatif oleh 3 dosen Fakultas Keguruan dan Ilmu Pendidikan serta satu 1 psikolog. Skala tersebut telah diujicobakan kepada 105 mahasiswa Fakultas Keguruan dan Ilmu Pendidikan Universitas Pekalongan Semester VII dengan hasil koefisien reliabilitas Alpha Cronbach sebesar 0,966.

\subsection{Teknik Analisis Data}

Analisis dilakukan secara kuantitatif dengan membandingkan skor pre-test dan posttest Skala Efikasi Diri Mengajar yang diperoleh oleh subjek penelitian dengan menggunakan uji Paired Samples T-test melalui program IBM Statistics 21. 


\section{Hasil dan Pembahasan}

Statistik deskriptif terhadap subjek penelitian disajikan pada Tabel1 1 .

Tabel 1: Statistik deskriptif subjek penelitian

\begin{tabular}{cccc}
\hline Subyek & & Rata-rata & Standar Deviasi \\
\hline$N=15$ & Pretest & 65,67 & 6,85218 \\
& Posttest & 81,27 & 14,75740 \\
\hline
\end{tabular}

Sebelum melakukan uji Paired Samples T-test, dilakukan terlebih dahulu uji normalitas data sebagai prasyarat. Hasil analisis uji normalitas Shapiro-Wilk menunjukkan nilai sig. sebesar 0,697 $(p>0,05)$. Hal ini menunjukkan bahwa data pada penelitian ini terdistribusi secara normal.

Hasil analisis data menggunakan Paired Samples T-test menunjukkan adanya perbedaan skor secara signifikan terkait efikasi diri mengajar pada subjek penelitian sebelum dan setelah mengikuti PPL. Nilai sig. (2-tailed) sebesar 0,001 $(p<0,05)$. Peningkatan skor diperoleh setelah mengikuti PPL, hal tersebut dapat dilihat pada data di mana rata-rata skor post-test $(81,2667)$ lebih tinggi dibandingkan rata-rata skor pre-test $(65,6667)$. Secara keseluruhan, terdapat peningkatan skor sebesar $23,76 \%$. Data tersebut menunjukkan bahwa PPL dapat meningkatkan efikasi diri mengajar mahasiswa Pendidikan Matematika secara signifikan

Hasil analisis data dapat dilihat pada Tabel 2

Tabel 2: Hasil Analisis Data

\begin{tabular}{lc}
\hline Pretest-Posttest & \\
\hline Mean & $-15,60000$ \\
Standar Deviasi & 13,56361 \\
Std. Error Mean & 3,50211 \\
t & $-4,454$ \\
df & 14 \\
Sig. 2 tailed & 0,001 \\
\hline
\end{tabular}

PPL sebagai program on the job training berdasarkan experiential learning mampu meningkatkan efikasi diri mengajar pada mahasiswa pendidikan matematika karena terpenuhinya empat sumber efikasi sebagaimana disampaikan oleh Bandura (Bandura, 1994, Bandura, 1997). PPL menyediakan mastery experience yang merupakan sumber paling kuat dalam menumbuhkan efikasi diri. Praktikan PPL memiliki waktu selama dua bulan dihadapkan pada kondisi nyata aplikasi bidang keilmuan, seperti mengajar, bersosialiasi, bernegosiasi, dan kemampuan manajerial kependidikan lainnya. Keberhasilan praktikan dalam menyelesaikan tugas-tugas nyata terkait dengan deskripsi kerja profesi guru membuat praktikan memiliki optimisme mampu menjalankan tugas sebagai guru profesional kelak.

Mughal dan Zafar [Mughal and Zafar, 2011] menyebutkan bahwa salah satu aspek dari experiential learning adalah reflective observation, yaitu melakukan pengamatan kepada orang lain terkait tugas yang dipelajari. Keberhasilan rekan PPL dalam menjalankan tugas-tugas magang dapat menjadi inspirasi dan dorongan untuk bisa mencapai keberhasilan dalam tugas yang sama. Karakteristik yang setara antarpraktikan dapat memunculkan identifikasi sosial, di mana ada perasaan mampu melakukan apa yang rekan PPL lain lakukan. Kondisi tersebut sesuai dengan sumber efikasi diri berupa vicarious experience ([Bandura, 1994, Bandura, 1997]), di mana keberhasilan orang lain seolah-olah ia rasakan sendiri karena adanya karakteristik yang setara. 
Selama pelaksanaan PPL, praktikan didampingi oleh guru pamong yang memiliki tugas di antaranya adalah membimbing dan memotivasi praktikan untuk menjadi calon guru yang berkompeten, membimbing praktikan dalam menyusun perangkat pembelajaran, mendampingi praktikan pada saat mengajar di kelas dan memberikan refleksi dari proses pembelajaran yang telah dilakukan. Dengan demikian, praktikan dapat memahami caracara terbaik untuk berhasil menyelesaikan tugas selama PPL. Adanya refleksi dan evaluasi sebagai umpan balik juga dapat meningkatkan efikasi diri [Pajares and Schunk, 2001]. Umpan balik berupa motivasi, refleksi dan evaluasi termasuk dalam verbal persuation yang dapat mendorong seseoang memberikan upaya yang lebih gigih untuk mencapai keberhasilan tugas Muretta, 2005.

Berdasarkan kuesioner yang diberikan kepada subjek penelitian, 100\% subjek menganggap berhasil program PPL yang telah ditempuh. Sebanyak 100\% subjek penelitian juga menyatakan perasaan positif seperti senang dan lega setelah berhasil menyelesaikan program PPL. Adanya suasana hati yang baik merupakan bagian dari physiological arousal yang merupakan sumber meningkatnya efikasi diri ([Bandura, 1994], (Bandura, 1997]).

Adanya suasana hati yang baik membuat seseorang cenderung memberikan penilaian positif kepada diri sendiri, demikian sebaliknya [Muretta, 2005]. Secara umum, ketika praktikan mengerjakan tugas-tugas PPL, mereka belajar tindakan mana yang dapat memberikan hasil terbaik, yang kemudian akan mereka terapkan di masa yang akan datang. Adanya gambaran strategi penyelesaian tugas dari guru pamong dan inspirasi keberhasilan rekan-rekan membuat mereka cenderung untuk bertahan dan berusaha menghadapi kesulitan. Ketika berhasil, perasaan positif yang muncul semakin memperkuat efikasi diri mengajar.

Analisis lanjutan dilakukan untuk mengetahui pengaruh PPL terhadap aspek-aspek efikasi diri, berupa magnitude, generality, dan strength. Data ketiga aspek telah terdistribusi normal, sehingga analisis dapat dilakukan menggunakan Paired Samples T-Test. Hasil analisis menunjukkan bahwa PPL dapat meningkatkan secara signifikan ketiga aspek efikasi diri mengajar pada subjek penelitian, yaitu skor magnitude meningkat $26,73 \%$ $(\mathrm{sig}=0,000 ; \mathrm{pi} 0,005)$, generality meningkat $22,60 \%(\mathrm{sig}=0,002 ; \mathrm{p} ; 0,005)$, dan strength meningkat 28,48 \% (sig=0,000; $\left.\mathrm{p}_{\mathrm{i} 0} 0,005\right)$.

Peningkatan skor tertinggi terjadi pada aspek magnitude, berupa keyakinan mampu menyelesaikan tugas mengajar dengan beragam tingkat kesulitan. Hal itu disebabkan program PPL memberikan praktikan tugas-tuas dengan tingkat kesulitan yang bergradasi, misalnya terkait dengan materi pembelajaran yang semakin sulit, demikian juga dengan karakteristik siswa yang beragam, di antaranya adanya yang tergolong sulit. Aspek Strength, berupa keyakinan utuk bertahan mengatasi kesulitan mengalami peningkatan skor tertinggi kedua. Durasi PPL selama dua bulan memberikan waktu yang cukup bagi praktikan untuk beradaptasi dengan kesulitan yang dihadapi, sehingga dapat melatih ketahanan kerja yang dimiliki. Aspek generality, berupa keyakinan untuk menyelesaikan berbagai jenis tugas meningkat meski tidak sebesar kedua aspek lainnya. Hal itu disebabkan praktikan memiliki pengalaman untuk mengajar beberapa kelas yang berbeda, dan mempelajari berbagai hal selain kegiatan mengajar. Namun demikian, PPL yang hanya dilakukan di satu sekolah pada satu jenjang pendidikan selama dua bulan membuat pengalaman praktikan masih terbatas pada jenjang sekolah tersebut.

\section{Simpulan}

Hasil analisis menunjukkan terdapat peningkatan efikasi diri mengajar pada mahasiswa Pendidikan Matematika setelah mengikuti PPL. Hal itu dikarenakan adanya pengalaman baru yang dimiliki terkait dengan adaptasi terhadap tugas-tugas yang dilaksanakan, adanya bimbingan dan umpan bailk dari guru yang berpengalaman, penguatan dari rekan kelompok yang berhasil dalam mengatasi tugas yang sama, dan perasaan positif atas 
keberhasilan melaksanakan tugas. Dengan demikian, subjek penelitian sudah lebih siap dalam menghadapi situasi yang serupa ketika mereka kelak menjadi guru profesional.

Penelitian ini memiliki beberapa keterbatasan, diantaranya adalah tidak adanya kelompok kontrol dan adanya kemungkinan situasi yang tidak sama yang dialami oleh masingmasing subjek karena lokasi PPL yang berbeda. Akan sangat baik untuk dapat mengembangkan penelitian serupa dengan melibatkan mahasiswa pada program studi lainnya, dan juga menganalisis efikasi diri mahasiswa berdasarkan jenjang sekolah tempat pelaksanaan PPL.

PPL sebagai on the job training yang mengimplementasikan prinsip experiential learning bagi para calon guru memiliki arti penting untuk membentuk pribadi yang berkompeten dalam tugasnya. Hal itu disebabkan guru merupakan profesi dengan tugas spesifik yang membutuhkan keterampilan, sehingga praktik lapangan merupakan sarana yang efektif untuk membantu calon guru beradaptasi terhadap tugas-tugasnya.

\section{Referensi}

[Alipour et al., 2009] Alipour, M., Salehi, M., and Shahnavaz, A. (2009). A study of on the job training effectiveness: Empirical evidence of iran. International Journal of Business and Management, 4(11):63.

[Ardiyanti, 2016] Ardiyanti, D. (2016). Aplikasi model rasch pada pengembangan skala efikasi diri dalam pengambilan keputusan karir siswa. Jurnal Psikologi, 43(3):248-263.

[Bandura, 1994] Bandura, A. (1994). Encyclopedia of human behavior.

[Bandura, 1997] Bandura, A. (1997). Self-efficacy: The exercise of control. Macmillan.

[Cook et al., 2002] Cook, T. D., Campbell, D. T., and Shadish, W. (2002). Experimental and quasi-experimental designs for generalized causal inference. Houghton Mifflin Boston.

[Gavora, 2010] Gavora, P. (2010). Slovak pre-service teacher self-efficacy: Theoretical and research considerations. The New Educational Review, 21(2):17-30.

[Ghufron, 2017] Ghufron, M. N. (2017). Kepuasan kerja guru paud ditinjau dari iklim kelas dan efikasi mengajar. QUALITY, 4(2):246-261.

[Kolb, 2014] Kolb, D. A. (2014). Experiential learning: Experience as the source of learning and development. FT press.

[Kolb et al., 2001] Kolb, D. A., Boyatzis, R. E., Mainemelis, C., et al. (2001). Experiential learning theory: Previous research and new directions. Perspectives on thinking, learning, and cognitive styles, 1(8):227-247.

[Mughal and Zafar, 2011] Mughal, F. and Zafar, A. (2011). Experiential learning from a constructivist perspective: Reconceptualizing the kolbian cycle. International Journal of Learning and Development, 1(2):27-37.

[Mukhid, 2009] Mukhid, A. (2009). Self-efficacy (perspektif teori kognitif sosial dan implikasinya terhadap pendidikan). TADRIS: Jurnal Pendidikan Islam, 4(1).

[Muretta, 2005] Muretta, R. J. (2005). Exploring the four sources of self-efficacy. PhD thesis, US: ProQuest Information \& Learning.

[Pajares and Schunk, 2001] Pajares, F. and Schunk, D. (2001). The development of academic self-efficacy. Development of achievement motivation. United States, 7. 
[Putri and Priambodo, 2015] Putri, R. M. and Priambodo, A. (2015). Pengaruh efikasi diri, penetapan tujuan dan kepuasan kerja pada pengembangan kompetensi guru pendidikan jasmani, olahraga dan kesehatan (studi pada guru pendidikan jasmani, olahraga dan kesehatan di sma negeri se-kota surabaya). Jurnal Pendidikan Olahraga dan Kesehatan, 3(1).

[Rustika, 2012] Rustika, I. M. (2012). Efikasi diri: Tinjauan teori albert bandura. Buletin Psikologi, 20(1-2):18-25.

[Safaria, 2016] Safaria, T. (2016). Peran efikasi diri, pola asuh otoritatif, dan motivasi berprestasi terhadap kematangan karir. Jurnal Psikologi, 43(2):154-166. 